\begin{tabular}{|c|c|c|}
\hline & Journal Homepage: $-\underline{w w w . j o u r n a l i j a r . c o m}$ & $\begin{array}{l}\text { INTERNATIONAL JOURNAL OF } \\
\text { ADVANCED RESEARCH (JJAR) }\end{array}$ \\
\hline ISSN NO. 2320-5407 & $\begin{array}{l}\text { Article DOI: } 10.21474 / \text { IJAR01/8600 } \\
\text { DOI URL: http://dx.doi.org/10.21474/IJAR01/8600 }\end{array}$ & \\
\hline
\end{tabular}

RESEARCH ARTICLE

\title{
EFFECT OF EXAMPLE NON EXAMPLE METHOD IMPLEMENTATION IN SCIENTIFIC APPROACH AND DISCOVERY LEARNING MODEL ON VII GRADE STUDENTS' AFFECTIVE COMPETENCE IN LEARNING NATURAL SCIENCE.
}

\author{
Amrianto ${ }^{1}$ and Lufri ${ }^{2}$. \\ 1. Student of Master Degree Program of Biology Education, Faculty of Mathematics and Natural Sciences, State \\ University of Padang. \\ 2. Lecturer of Biology Department, Faculty of Mathematics and Natural Sciences, State University of Padang.
}

\section{Manuscript Info}

……………………

Manuscript History

Received: 02 January 2018

Final Accepted: 04 February 2019

Published: March 2019

Key words:-

Example Non Example, Scientific,

Discovery, Affective.

\begin{abstract}
The 2013 Curriculum emphasizes on active learning pattern. However, based on the questionnaire spread in junior high school 18 Padang, it was gotten the result that teachers still have difficulty in implementing it, especially in affective competence of confidence. The affective competence of confidence will encourage students to be active in learning process, both in asking questions and expressing opinion. In cooperative learning, students are provided a vehicle to increase their confidence through presenting their discussion result in front of the class. By considering this issue, there is an alternative solution that can be used by teacher, which is example non example method. This method is one of cooperative learning method. Besides that, it can support the implementation of scientific approach and discovery learning model in learning process. The scientific approach and discovery learning model are the approach and model recommended in the 2013 Curriculum. Purpose of the research was to know effect of example non example method in scientific approach and discovery learning model on students' affective competence. It was a quasiexperimental research. It was done in junior high school 18 Padang to grade VII students. The instrument used was written test in form of multiple-choice and essay. Technique of data analysis used Mann Whitney U test. It was done by using SPSS software. The finding shows that example non example method in scientific approach and discovery learning model has significant effect on students' affective competence, with sig. value $(0.036)<0.05$.
\end{abstract}

Copy Right, IJAR, 2019,. All rights reserved.

\section{Introduction:-}

The 2013 Curriculum requires some improvements of mindset or pattern in learning process, such as from teachercentered learning to student-centered learning, from passive learning to active learning, and from classical learning to cooperative learning (Kemendikbud, 2013). In the academic year 2017/2018, the 2013 Curriculum starts being implemented in school. For example, from 95 junior high school (state or private institution) in Padang, there are 60

Corresponding Author:-Amrianto.

Address:-Student of Master Degree Program of Biologi Education, Faculty of Mathematics and

Natural Sciences, State University of Padang. 
junior high school have implemented the 2013 Curriculum and the others still implement KTSP Curriculum (Kemendikbud, 2018). In other word, 63\% of junior high school in Padang have implemented the 2013 Curriculum.

Based on the requirements of the 2013 Curriculum and its implementation in school, it was conducted a preliminary research done at August $8^{\text {th }}, 2018$ in junior high school 18 Padang, as a school which has implemented the 2013 Curriculum. The preliminary research was done to identify problems faced by teachers and students through spreading questionnaires. Result of the questionnaires showed that teachers have been able to design learning media suitable with the 2013 Curriculum conditions. However, its implementation is not maximum yet. There are still some problems faced by teachers in learning process.

The main problem faced by teachers in learning process is the difficulty to make students active during learning process, especially in asking questions and expressing their ideas or opinion. From the questionnaires, $82 \%$ of students rarely ask questions in learning process, while $87 \%$ of students are not brave to deliver or express their ideas and opinion. Another problem, based on the questionnaire, is $55 \%$ of students are not confident with their ability. Based on the data above, it is concluded that students have problems in their affective competence, which is their confidence in asking questions and expressing their ideas or opinion is low.

One way to solve the problems is using active learning in learning process. Through active learning, students are required to be active. As a result, they will be easier to understand a learning material. It is in line with Lufri et al. (2018), who say that through active learning, students can understand learning materials more easily. The importance of implementing active learning is also explained by Lufri et al. (2016), who state that active learning should be developed. It is because the active learning includes in student-centered learning model.

Based on problems faced by students and the 2013 Curriculum requirements, there is an alternative solution to solve the problems, which is implementation of example non example method in scientific approach and discovery learning model. The example non example method in discovery learning and scientific approach has never been implemented yet by teacher who taught VII grade at junior high school 18 Padang. Consequently, its effect on students' affective competence is not surely known yet, especially for VII grade students of junior high school 18 Padang.

Consideration of choosing discovery learning model is because it is accustomed to be used by teacher so that it will not disturb learning process in implementing it in classroom. Another consideration is it is a suggested model to use in the 2013 Curriculum. Moreover, it can improve students' learning outcomes (Arifani, 2016). The use of scientific approach in learning process is a requirement of the 2013 Curriculum. It is mentioned in Permendikbud No. 103 year 2014. The scientific approach can make students active in learning process (Firman et al., 2018; Mardiyani, 2016). Based on the previous research done by Said et al. (2016), it is explained that the scientific approach is excellent for being combined with cooperative learning because it can improve student's competences.

The example non example method is a learning method which uses pictures as media to deliver learning materials. By using this method, students are encouraged to think critically through problems existed in the pictures. According to Hosnan (2014), the example non example method includes in cooperative learning. Therefore, it is the main consideration to implement this method in this research.

Another consideration in choosing this method is it is appropriate or suitable to be collaborated with discovery learning model and scientific approach. The appropriateness is about interrelationship of learning method, model and approach. In discovery learning model, students are required to be independent in learning through discovery. The discovery cannot be separated from scientific activity so that it needs scientific approach. Besides that, the discovery needs media in delivering information, such as pictures so that it needs example non example method. It is in line with Briggs (2001), who state that the contrast pictures is very important to support discovery learning.

Other consideration of choosing example non example method is its suitability with learning materials taught by teacher, which are KD (basic competencies) 3.6 (Life Organization System) and KD 3.7 (Organism Interaction). The learning material of KD 3.6 (Life Organization System) discusses about abstract materials. So, it is appropriate to give examples in form of pictures because basically, learning process occurs $30 \%$ from seeing the materials (Hosnan, 2014). It is same with KD 3.7 (Organism Interaction), which is more about field observation activity (observing environment). When students cannot observe unaffordable objects, it can be observed by providing 
pictures as media to facilitate the observation in order to support discovery activities. Based on the previous research related to example non example method, it is known that there are some strengths of this method. They are 1) it is effective to increase students' activities in learning process (Saputra, 2017; Setyaningsih el al., 2013) and 2) through example analysis activity, students can be facilitated to learn to prove knowledge (Suryani et al., 2016). By considering problems faced in classroom, the example non example method in discovery learning model and scientific approach is expected to give different and comfortable learning atmosphere. The different learning atmosphere can attract students to pay attention to the learning material and understand it (Lufri et al., 2018). Therefore, it was interesting to do a research, entitled: "Effect of Example Non Example Method Implementation in Scientific Approach and Discovery Learning Model on VII Grade Students' Affective Competence in Learning Natural Science".

\section{Research Method:-}

It was a quasi-experimental research. It was done in grade VII of junior high school 18 Padang in semester II of academic year 2018/2019. Population of research was all VII grade students in junior high school 18 Padang, who are registered in academic year 2018/2019. They are 228 students from 9 classes. Sample was taken by using purposive sampling technique by considering some criteria. The criteria are the sample classes are taught by same teacher and have similar variance scores (in order that the treatment effect can be seen clearly).

The first criterion was the classes are taught by same teacher. So, this research was done to two classes taught by Mrs. Deswita, S. Pd., which are VII.6 and VII.8. Next, the second criterion was the classes have similar variance score. To know it, homogeneity test was done to two classes. It was done by using daily test (UH) scores as data. Result of the homogeneity test shows that sig. value of both classes is 0.120 , which means that both classes have similar variance (if sig. Value $>0.05$, the two sample classes have similar variance). In addition, this research used Randomized Control-Group Posttest Only Design.

Research instrument used was affective observation sheet. It is completed with scoring rubrics to facilitate observers in scoring students' affective competence. It was also validated by two experts and one Natural Science (IPA) teacher. The data processing uses SPSS software. It is used to process the data in form of numbers statistically, which are homogeneity test, normality test and hypothesis testing.

Technique of data analysis was done through hypothesis testing. Statistical test used was Mann-Whitney U-Test because the data are nominal. The criteria of hypothesis testing by using Mann-Whitney U-Test are as follow.

1. $\mathrm{H}_{0}$ is accepted if sig. value $>0,05$.

2. $\mathrm{H}_{0}$ is rejected if sig. value $<0,05$.

\section{Description:}

$\mathrm{H}_{0}$ : there is no effect of example non example method implementation in scientific approach and discovery learning model on grade VII students' Natural Science (IPA) affective competence in junior high school 18 Padang.

$\mathrm{H}_{1}$ : there is an effect of example non example method implementation in scientific approach and discovery learning model on grade VII students' Natural Science (IPA) affective competence in junior high school 18 Padang.

\section{Finding and Discussing:- \\ Finding}

Data of students' affective competence are obtained from observation done by teacher and peer as observers by using affective observation sheet. The observation was done while learning process was going on. The data of students' affective competence can be seen in Table 1 below.

Table 1:-Average Score, Maximum Score, and Minimum score of experimental and control classes in Affective Competence

\begin{tabular}{|c|c|c|c|c|}
\hline Class & $\mathrm{N}$ & Average & $\mathrm{X}_{\max }$ & $\mathrm{X}_{\min }$ \\
\hline Experimental & 32 & 86.37 & 100 & 57.50 \\
\hline Control & 32 & 81.89 & 100 & 60 \\
\hline
\end{tabular}


Based on Table 1 above, it is known that the average score of affective competence in experimental class (86.37) is higher than in control class (81.89), while, the highest score in both classes is 100 and minimum score in experimental class is 57.50 and in control class is 60 .

Next, hypothesis testing was done by using Mann-Whitney U-Test because it is ordinal data. The result of hypothesis testing can be seen in Table 2 below.

Table 2:-Result of Hypothesis Testing

\begin{tabular}{|c|c|c|c|}
\hline Class & Sig. & A & Desc. \\
\hline Experimental & 0.036 & 0.05 & \multirow{2}{*}{$\mathrm{H}_{0}$ is rejected } \\
\hline Control & 0.05 \\
\hline
\end{tabular}

Based on Table 2 above, it is known that the significant value of the hypothesis testing is 0.036 . It means that sig. value $<0.05$, so $\mathrm{H}_{0}$ is rejected. Therefore, it can be concluded that there is an effect of example non example method in scientific approach and discovery learning model on grade VII students' Natural Science (IPA) affective competence in junior high school 18 Padang.

\section{Discussion:-}

Based on the research finding, students' average score of affective competence in experimental class (86.37) is higher than in control class (81.89). The improvement of affective competence in this research is in indicators of discipline, confidence, responsibility, cooperation and politeness. The improvement is affected by learning method, model and approach which are used, especially in group learning activity (example non example method), as explained by Sanjaya (2012), that group learning can improve students' confidence, thinking skill, idea sharing, cooperation and responsibility.

The result of hypothesis testing also shows that $\mathrm{H}_{0}$ is rejected, so $\mathrm{H}_{1}$ is accepted. It means that there is an effect of example non example method in scientific approach and discovery learning model on students' affective competence in learning IPA. The effect is clearly seen in cooperative and confidence indicators. Students in experimental class have better achievement in confidence and cooperative indicators than students in control class.

It is caused by the example non example method is one form of cooperative learning which supports students in improving cooperation in group. It is in line with Huda (2014), who states that cooperative learning can be more efficient than working individually. In this research, students in control class still used individual learning (classical).

Another affective competence which improves is confidence. It is seen from indicators, such as students are dare to present their discussion result and students are dare to ask, answer and respond questions. These indicators are done in example non example method (in discussion activities), discover learning model (in verification stage) and scientific approach (in activity to communicate), which is implemented in experimental class.

Through affective competence of confidence, it will support the implementation of active learning and studentcentered learning. It is same with opinion of Otta et al. (2018), who propose that the strength of example non example method is it gives opportunity for students to express their opinion. Through picture analysis and group discussion, they are given opportunity to say their ideas so that they are more active in learning process.

It is in line with Suryani et al. (2016), who explain that example non example method can improve students' activities in learning process. Besides that, discovery learning model can also improve students' performances during learning process (Takacs \& Ardiana, 2017). It proves that through example non example method in scientific approach and discovery learning model can improve students' affective competence.

\section{Conclusion, Implication and Suggestion:-}

\section{Conclusion}

Based on the finding of the research, it is concluded that there is an effect of example non example method implementation in scientific approach and discovery learning model on VII grade students' affective competence in learning Natural Science in junior high school 18 Padang. 


\section{Implication}

The significant improvement of students' affective competence is in indicators of confidence and cooperation. By achievement of these indicators, it makes students more active in learning process so active learning and studentcentered learning can be done.

\section{Suggestion}

Based on the conclusion and implication above, there is a suggestion for further research in the future. The suggestion is observation process should be done to groups, not to individuals so that the observer is easier to observe students' affective competence indicators.

\section{Acknowledgments:-}

Acknowledgements to Prof. Dr. Lufri, M.S as advisor and validator, Deswita, S.Pd as validator and big family of junior high school 18 Padang which allows researcher to do the research.

\section{References:-}

1. Arifani, Y. (2016). The Implementation of Team-Based Discovery Learning to Improve Students' Ability in Writing Research Proposal. Canadian Center of Science and Education, 9(2), 111-119.

2. Briggs, C. L. (2001). Discovery Learning, Cognitive Psychology of. Elsevier: International Encyclopedia of the Social Science, 3736-3739.

3. Firman, Baedhowi, and Wiedy, M. 2018. The Effectiveness of the Scientific Approach to Improve Student Learning Outcomes. International Journal of Active Learning, 3(2), 86-91.

4. Hosnan. (2014). Pendekatan dan Kontekstual dalam Pembelajaran Abad 21. Jakarta: Ghalia Indonesia.

5. Huda, H. (2014). Model-model Pengajaran dan Pembelajaran. Yogyakarta: Pustaka Pelajar.

6. Kemendikbud. (2013). Permendikbud Republik Indonesia Nomor 68 Tahun 2013. Jakarta: Kemendikbud.

7. Kemendikbud. (2018). Data Sekolah Kemendikbud Tahun Pelajaran 2017/2018, (Online), (http://sekolah.data.kemdikbud.go.id/index.php/chome/pencarian/, retrieved on February 27, 2018).

8. Lufri, Fitri, R., and Yogica, R. (2018). Development of Learning Models Based on Problem Solving and Meaningful Learning Standards by Expert Validity for Animal Development Course. In IOP Conference Series: Materials Science and Engineering, 335(1), p. 012094. IOP Publishing.

9. Lufri, Sudirman, S., and Rahmi, S. (2016). Mengembangkan Skill Mengajar (Teaching Skill) Mahasiswa Calon Guru Menggunakan Multy Strategies. Ta'dib, 15(1).

10. Mardiyani, D. (2016). Penerapan Pendekatan Saintifik untuk Meningkatkan Kemampuan Pemahaman dan Pemecahan Masalah serta Disposisi Matematis Siswa SMAN 5 Sukabumi. Thesis. Jawa Barat: Universitas Pasundan.

11. Otta, L. E., Tara, S. C., Diana, S. H., William, R. L. (2018). Discovery Learning: Development of a Unique Active Learning Environment for Introductory Chemistry. Journal of the Scholarship of Teaching and Learning, 8(4), 161-180.

12. Said, I. M., Eddy, S, and Machmud, S. (2016). The Scientific Approach-Based Cooperative Learning Tool for Vocational Students Vocation Program of Autotronic (Automotive Electronic) Engineering. IOSR Journal of Research \& Method in Education, 6(3), 67-73.

13. Sanjaya, W. (2012). Strategi Pembelajaran Berorientasi Standar Proses Pendidikan. Bandung: Kencana Prenada Media Group.

14. Saputra, S. (2017). Ketuntasan Belajar Siswa pada Materi Protista dengan Menggunakan Metode Example Non Example pada Konsep Protista. Jurnal Variasi, 9(2), 21-14.

15. Setyaningsih, Y., Margereta, R., Bambang, P. (2013). Penerapan Metode Example Non Example dalam Pembelajaran Keanekaragaman Hewan di SMPN 2 Tengaran Kabupaten Semarang. Journal of Biology Education, 2(2): 156-164.

16. Suryani, K., Rusdi, Syafri, M. (2016). Penerapan Metode Examples Non Examples untuk Meningkatkan Akivitas dan Hasil Belajar Matematika Siswa Kelas VII SMP Al-Karim Kota Bengkulu. Thesis. Bengkulu: Universitas Bengkulu.

17. Takacs, Z. K., Adriana, G. B. (2017). How Pictures in Picture Storybooks Support Young Children's Story Comprehension: An Eye-Tracking Experiment. Elsevier: Journal of Experimental Child Psychology, 174, 112. 